\title{
A Reconsideration \\ of Translation Quality and Standards
}

\author{
Rosemary Mitchell-Schuitevoerder* \\ Newcastle University (UK) \\ Newcastle upon Tyne, Tyne and Wear \\ $N E 17 R U, U K$
}

Received 21.10.2015, received in revised form 30.10.2015, accepted 20.11.2015

Translators and language service providers invariably offer their services while proclaiming superior quality. They are supported by professional translation and interpreting organisations which emphasise their dedication to practitioners as well as their aim to enhance language skills in the public interest by means of accredited qualifications. This article will not only review the concept of quality from the perspective of the different stakeholders in the translation process from providers to buyers, but also consider whether new models for standards and different levels of quality would not give more clarity in the translation industry. In order to improve the quality of translations there will need to be a greater emphasis on self-assessment and revision in translator training at root level. Meanwhile professional organisations should not only maintain and improve standards, but also promote more visibility of quality and standards to all stakeholders, from translator to client.

Keywords: professional organisations, translation briefs, tiered quality models, standards, selfassessment.

DOI: 10.17516/1997-1370-2015-8-12-2908-2919.

Research area: translator training.

\section{Introduction}

The UK consumer magazine Which? claims that it offers thousands of impartial (sic) product reviews, which cover both products and services so that consumers can make the best purchase decisions to suit their needs. The magazine is popular and apparently has over one million subscribers. Its reviews are considered reliable, as they are based on the outcome of tests. Moreover, they are factual and state whether the product is red or green, economical, durable, sustainable, of good or poor quality. The tests are conducted in compliance with recognized norms and ISO standards. Consequently, features can be ticked and scores will be given. Although two professional UK organisations for linguists and translators, the Chartered Institute of Linguists (CIOL) and the Institute of Translation and Interpreting, currently only have a combined membership of about 7000 commitment to the maintenance of good standards and the quality of their products has the same importance for each organisation. The readership of ITI Bulletin and the The Linguist (CIOL) is not likely to match

(C) Siberian Federal University. All rights reserved

* Corresponding author E-mail address: journal@sfu-kras.ru 
the million subscribers to Which?, but it might increase if the clarity of objectives as well as visibility of the organisations improves.

In this article I will review current quality standards and norms in the translation industry and propose different ways in which standards can be applied to benefit both translators (and LSPs) and their clients. Part of this clarity will depend on the role played by multiple stakeholders, i.e. translator trainers, professional organisations, professional and amateur translators, in achieving, accepting and maintaining a variety of standards appropriate to individual bodies and circumstances or requirements.

\section{Perceived translation quality}

The internet displays many positive qualifiers of translation quality: 'superior', 'expert', 'professional', 'accurate', or 'enhanced' [by machine translation (MT)]. The agency offering 'MT enhancement' appeals to the air of mystery surrounding machine translation. Their advert aims to remove the fear of poor MT quality and praises its beneficial features, such as time and cost efficiency, as well as increased productivity. Translation 'quality' enhanced by MT is described in the advert as follows: MT can be used for texts in which high quality is not necessary, for instance when industry and business use MT as a quick way to acquire gist translations. The implication here is that 'quality' is not and need not be generic or standard, but that it can be variable and can conform to the purpose of the translation. MT can have enhancing qualities depending on its function: the agent can use it to check idiomatic accuracy, and the translator can use it as an additional dictionary, e.g. as a plugin in a translation memory programme, where it may give excellent up-to-date suggestions. In this capacity, MT is used as a tool and the translator remains responsible for translation quality. It is not uncommon for clients to reject a translation as 'a Google Translate' (GT) by which they mean that they do not approve of the quality. Clients are not always capable of producing evidence if they are unfamiliar with target or source language, and therefore rely on third party comments. In such cases translators may be asked to prove the originality and quality of the perceived 'Google Translate'. However, GT can also be used to check the accuracy of translated work. It allows LSPs to check if anything is missing from the translation, although they have to rely on the translator for grammar and style.

'Quality' becomes an unhelpful concept when the client cannot provide details of assumed inferior quality, or when the LSP cannot guarantee a complete 'quality check'. Maybe the term should be replaced by another concept or model with more specificity, so that a translation can be requested and delivered according to agreed benchmarks, criteria, levels or thresholds (Mitchell-Schuitevoerder 2015).

The following benchmarks are commonly used by LSPs: 'ISO 9001:2008 \& EN 15038:2006 as quality certificates', but the question is whether they give clients a clear picture of translation quality. ISO 9000 is a set of Standards for quality management systems maintained by ISO, the International Organization for Standardization. The Standards are administered by accreditation and certification bodies. Some of the requirements include procedures to cover all key processes, monitoring processes, keeping good records, error checking, continued improvement. EN 15038 is a quality standard which was set by the European Committee for Standardization specifically for the translation industry and focuses mainly on procedures in translation services. LSPs will benefit from compliance to such standards, but in the end it is translators who are responsible for delivering the standards, which they can only do if the stakeholders, LSP, translator or client, have 
a clear picture of the standards they wish to achieve, deliver and receive.

\section{Professional standards compared}

A standard can be defined as a level of quality, and as a measure or model in comparative evaluations. The Merriam-Webster indicates an element of subjectivity in that a standard is a level of quality that is considered acceptable or desirable. The difficulty defining standards begins as soon as a standard is set and is often exacerbated when the user challenges the standard according to their individual assessment of the end product. It should be noted however that a standard can only be challenged when one has been set, and is presented with an aura of uniformity and agreement. The industry, whether commercial or professional, has different ways of expressing standards.

The consumer's organisation Which? is pertinent and informs the public about quality and standards so that consumers can make informed purchases:

Which? magazines offer you a wealth of expert advice and information on a vast range of products and services. Each issue of Which? is packed with reports on everything that affects the quality of your life. From everyday products and services to one-off investments, we help you to get the best deals available.

www.which.co.uk 2015

The Chartered Institute of Linguists introduces itself on the web as a high quality organisation and states its objectives:

CIOL is the pre-eminent UKbased professional membership body for language practitioners. It aims to enhance and promote the value of languages and language skills in the public interest and provides accredited qualifications through the IoL Educational Trust.

www.ciol.org.uk 2015

In its journal, CIOL lacks specificity and does not necessarily mention the standards which are set out in the articles of the organisation. The Linguist (2015:2) informs the reader that 'it is the official journal of the Chartered Institute of Linguists', but without any mention of standards, aims or objectives. The contents page however reveals that achievement, the setting and maintaining of standards are main concerns, e.g. 'How to stop boys falling behind in languages', 'A look at IoLET's new business qualification', 'Closing the gap in translation assessment', and 'Setting standards'. The logo of the Institute of Translation and Interpreting bears the following subtitle on its web page: 'Promoting the highest standards in the profession' (www.iti.org.uk 2015). Its dedication to practising translation and interpreting professionals is stated on the web, and in ITI Bulletin, its journal. The content page of Bulletin (July/August 2015) lists features relating to standards, such as 'Views from a firsttime speaker, plus professional conduct', and events for corporate professional development (CPD).

What prevents professional translation organisations from being clear and definitive about the quality of their members' translation products and services? A client wanting to know standards and the quality of potential translations is unlikely to find an answer in the language journals. Clients are quick to praise or condemn standards, which is not helped by producers who are cautious in the ways they promote their quality products. Their hesitance might be caused by an ignorance of requirements, which is unfortunately a common trait in the translation 
industry. Information to translators about the product, the client or target audience can be minimal (see Fraser 2000), which also applies to feedback. Translators cannot rely on a flood of questionnaires and surveys generated by their end products in order to give them helpful feedback. A focus on quality standards determined by the client's requirements could be an improvement to all parties involved in the translation process, instead of leaving quality entirely in the hands of the translator.

\section{ISO standards and the industry}

A new ISO norm for translation services includes a number of pertinent recommendations, which affect not only the translation service provider (TSP) but also the client's specifications:

\section{ISO 17100:2015 provides requirements} for the core processes, resources, and other aspects necessary for the delivery of a quality translation service that meets applicable specifications. Application of ISO 17100:2015 also provides the means by which a translation service provider (TSP) can demonstrate conformity of specified translation services to ISO 17100:2015 and the capability of its processes and resources to deliver a translation service that will meet the client's and other applicable specifications. Applicable specifications can include those of the client, of the TSP itself, and of any relevant industry codes, best-practice guides, or legislation. The use of raw output from machine translation plus post-editing is outside the scope of ISO 17100:2015. ISO 17100:2015 does not apply to interpreting services.

http://www.iso.org/iso/catalogue detail.htm?csnumber $=59149: 2015$
ISO 17100 Translation Services Management Standard has superseded the old European quality standard BS EN 15038 for Translation Service Providers that was set up by the European Committee for Standardisation in 2006. The BS EN standard continues to be embraced by many language service providers as a stamp of approval indicating that their products are delivered with an acceptable quality. The sector's initial enthusiasm for the BS-EN 'fit for purpose' standard possibly finds its source in a lack of agreement in the industry (see Gouadec 2007; Pym 2010) as to what a standard should entail. One of the differences between ISO 17100:2015 and the earlier BS EN 15038:2006 'fit for purpose' standard is that the ISO contains an additional competence requirement in the form of 'domain confidence', which refers to agreement between the inputted utterance and the application of the end product, as well as discourse coherence. This involves being able to translate into the target language using appropriate style and terminology. Another key difference is that there is a far greater focus on the customer so as to bring it closer to the ISO 9001 Quality Management Standard. Examples of which include:

- The identifying of the key customer requirements prior to production

- The handling and processing of customer feedback and,

- The delivering of the service as a whole.

Revision and translation assessment/ evaluation are closely related to quality and standards. They have always taken a central position in research (see House 1997, Nord 1997, Cronin 2010). Sharon O'Brien's (2012) dynamic quality evaluation model for translation breaks with the standard 'error typology', which is commonly used by many LSPs who still use the fit-for-purpose principle as their quality safeguard. O'Brien explains how communication channel, content profile and the parameters of utility, 
time and sentiment can be the building blocks of a different approach to what establishes good quality. O’Brien (2012) observes that 'quality is closely linked with customer opinion and yet quality evaluation in the translation industry is managed by gatekeepers in the supply and demand chain who work with static evaluation models'. Possibly the existing models are a form of security, which LSPs apply to large volumes of translation that are generated by a pool of non-homogenous freelance translators who will undoubtedly vary in quality.

This in fact highlights another issue, viz. the reliance on revisers, reviewers, or proofreaders to ensure the good quality of the original translation. One LSP highlights the benefits of revision as described in the BS EN standard:

the standard's most outstanding features are firstly, that it defines the translation process where quality is guaranteed not by the translation which is just one phase in the process, but by the fact of the translation being reviewed by a person other than the translator, and secondly it specifies the professional competences of each of the participants in the translation process, mainly translators, reviewers, revisers and proofreaders.

http://qualitystandard.bs.en-15038.

$\underline{\mathrm{com} /}$

The concept of revision as a must does not necessarily guarantee good practice. In e.g. the manufacturing industry a refrigerator or car is made to high standards of perfection and the final check is meant to ensure that they have been met, not to remedy the flaws of a poor quality product. The translator needs to take full responsibility for the quality of their work, set by reasonable and agreed standards. The translation industry requires good, recognisable standards, which should be negotiated between client and translator in a game of fair play, and not by kicking the ball into the translator's court.

\section{Translation standards and translation briefs}

The recommendations in ISO 17100:2015 cannot guarantee that translations meet the quality standards anticipated by the client. A translation does not have the same quantifiable features as e.g. whitegoods. The components of a refrigerator can be counted, measured and tested by multiple assessors and produce a uniform assessment. In comparison, two assessors of the same translation may well reach an agreement, but it is not likely that they will share each other's opinion on all points.

If the client is not the end user of the translation or does not know the source or target language, they will have to trust that the translation meets quality standards. Many LSPs have procedures in place to check the quality of a translation, but their translation briefs cannot be comprehensive and specific if the client has not supplied the required information about the target audience, purpose of the translation and available in-house terminology. Fraser's survey (2000:51-73) on translator practice shows that practitioner translators often receive poor briefing or none from the client, and any feedback other than complaints is rare. If clients were to include a brief which clearly outlines what they need, rather than what they want, and gave a clear description of the target audience, would not this lead to a set of quantifiable criteria which could be met by the translator? Some LSPs tend to send the same brief to their translators for most assignments:

\section{INSTRUCTIONS}

- The font used throughout the document is Helvetica Neue. 
- Please translate all text that appears in the main slides and the speaker notes panel.

- Please translate the 'Section' headings that appear in the slide thumbnails panel.

- Please do not translate words that are brand names or product names.

- Where possible, please try not to adjust the width, height or position of the text boxes. If the translated text doesn't fit then please reduce the size of the text.

- If your language does not display properly in the Helvetica Neue font then please substitute for Arial or a similar sans serif font.

(LSP translation brief 2015)

If specific briefs were practice, translation quality and standards could meet targets. Briefs could provide more transparency to all stakeholders involved in the translation process - practising translators, translator trainers, student translators, amateur translators, as well as professional organisations for translators. Standards could be determined in line with the brief which would improve the ultimate quality.

\section{A move away}

\section{from existing standards}

Quality is not necessarily a given fact. It needs to be achieved and tested. In translation it can undoubtedly be realised, but how can translations be tested with an acceptable degree of conformity? In fact, there are several types of translation which fall outside any concept of standard or quality. Firstly, although machine translation is mentioned, it is not included in ISO 17100:2015. A reason for exclusion could be its potentially collaborative nature: MT often involves human pre-editing and post-editing, which can make the process and product more difficult to assess. The current ISO standard places a greater focus on continuous improvement and customer satisfaction, and any discrepancies in terms of quality may be considered part of the ISO 17100 standard's processes and procedures. MT inclusion is only a matter of time.

Another category of translation which does not offer quality insurance is that by fansubbers or crowdsourcers. They do not need to comply with standards or quality. The fansubbers are fans who subtitle films in groups, they do not charge for their services, but do not necessarily have any translation qualifications. Crowdsourced translations may consist of a mix of human and machine translation, and the involvement of different groups of non-professionals, once again free of charge. Gambier (2015:349-50) presents these non-profit translations as a new challenge to translators and researchers. The new group of non-professionals, crowdsourcers and fansubbers, will undoubtedly throw a spanner in the wheel of quality and standards, while software such as Translation Memory and Machine Translation present translators with technological challenges in the way they work. The new nonprofessionals stakeholders and technological procedures could cause a further breakdown, or at least a diversification of standards. Gambier also highlights collaboration as a socioprofessional challenge due to the volume of (EU) documentation requiring teamwork, or caused by other forms of cooperation in order to produce translations on time.

If existing standards cannot be applied, it has been suggested that we change the way in which we apply standards, or adopt different models. Lommel (2013:227-8) observes that typical pricing models in Western Europe and North America treat quality as a constant, without questioning the differences between providers, the various ways in which translations are generated (collaboration, technological support, human and/or machine translation), which subsequently makes quality assessment more difficult for 
buyers. Lommel, senior consultant of the German Research Center for Artifical Intelligence (DFKI), draws attention to the 'tiered pricing models' used in Russia where the cheapest and basic level is a 'raw' translation without revision or review, whereas a full revision meets the highest level accompanied by the highest price. Lommel adds that the advantage of the differential pricing model is a move towards more transparency so that the buyers will have a better idea of price cum quality and can also ask for a translation that meets their needs. He simultaneously warns that the system is based on trust and on the reliance that the buyer receives what they requested and is not given a basic translation while paying the full price. Muzii (2012) follows a similar line: the translator quotes according to the quality of the translation and does not haggle about the cost as if standing in an auction hall. And if clients dispute quality, maybe the translator would benefit from offering a translation according to the following classification set up by the EAGLES working group (Experts Advisory Group on Language Engineering Standards) in the 1990s:

1. Raw translation, which may contain minor grammatical or syntactic errors without impeding comprehension; to be used for large amounts of scientific material

2. Regular quality translation, which transfers the information grammatically correctly but may be lacking in style correctness; to be used for technical manuals

3. Extra quality translation; both fluent and idiomatically and accurate, culturally correct in the target language; to be used for advertisements and literature

4. Adaptation, which is not a direct translation of an original text; to be used for press releases and advertising

Muzii draws an analogy between the purchase of cars and translations. He suggests that when we buy a car, we want to know what the vehicle can and cannot 'do'. In a new car, we expect a different quality to that of a second-hand car, yet both should be structurally sound and do the job. External imperfections in a showroom car will not affect the performance and can be addressed by the recipient. So why shouldn't translations be offered at different qualities and different prices? Muzii does not believe in educating the client, which is often suggested as a way forward by practising translators, LSPs and professional organisations. He suggests that translation providers should 'profitably' signal what they offer in such a way that the buyer can understand and will accept the price tag. If all providers claim that they deliver 'top quality', it is not surprising that buyers move on to choose cheaper services, says Muzii. In other words, translation providers need to be clear about the translation's quality, its purpose (who is going to read the translation and for what purpose), and its price (adapted to its purpose - lower for gist, higher for publication). Offering quality is fine, but not without a detailed understanding of the quality concept by both parties, providers and recipients. The ISO 17100:2015 is an industry standard, which does not define the ultimate quality of the product, it outlines the processes and good practices in order to produce quality-translations. This opens opportunities to stakeholders such as practising translators, trainers, professional organisations and non-professional stakeholders to be involved in defining their own quality standards to match the brief and meet the client's requirements.

\section{Student training and self-assessment}

Revision is time consuming and costly in time and money. It need not be a general requirement if translations are delivered according to a tiered pricing/quality model. This does not mean that poor quality is acceptable; on the contrary, practising translators need to practise a high level 
of revision. As many translators are currently trained in academic institutions, revision and self-assessment should be a top training priority. The following comment by a practising translator, a reviewer of students' translation portfolios suggests that students do not always demonstrate good competence in self-assessment (MitchellSchuitevoerder 2014):

Almost every piece of work [four] from each student shares the same problem, which is the absence of conjunctions. This consistent problem clearly reduces the readability as the reader hardly finds any logical connection between the sentences or paragraphs. What causes this problem, in my opinion, is that most of the students may not have revised or even read their translation after exporting them from CAT tools where the translation is merely done in a sentence-by-sentence manner. They should have achieved better results if they could simply spend a little more time being a reader of their own translation.

(Durham University 2011)

Even if peer revision takes place, students are ultimately responsible for their final translation. Brown et al. (1997:178) argue that the students' selfassessment skills can enhance their development of professional competence, which should be one of the main objectives within translator training. In addition, computer-assisted translation tools can support the learning process. They provide major revision possibilities and therefore should assist self-assessment. If the students use them (well), the tools should contribute towards wellrevised and high-standard translations.

The encouragement of self-assessment will present translator trainers with a pedagogical challenge. Firstly, the root cause of the students' initial reluctance to carry out thorough self- assessment needs to be understood. Avoidance might lie in a poor understanding of the applied teaching method, unfamiliarity with self-reflective learning practices, or poor intrinsic motivation. Secondly, regardless of the students' educational backgrounds and difference in learning styles, trainers will need to implement motivational strategies to enhance self-assessment during the entire process. Students need to be taught and shown not only what to learn and how to learn, but also to be aware of the significance of translation skills which include self-assessment. Thirdly, translator trainers need to show students the benefits and importance of continued professional development (CPD). Student translators as well as practising translators need to become independent learners.

The assessment challenge also affects the translator trainer. Apparently, teachers know how they themselves learn, but do not necessarily consider how their students learn, or if the way they teach will enable learning to happen (Fry et al. 2005:9). This point of view is endorsed by Brown et al. (1997) who include assessment as a skill that needs to be learnt: if student and teacher are to share the objectives of assessment, the teacher will have to explain the objectives clearly and repeatedly. Strong teaching skills are required in order to achieve a successful participation of students in collaborative e-learning environments (Garrison 2003:102), such as webinars, which will undoubtedly be a substantial contributor to potential CPD. The pedagogical challenge to overcome negative attitudes to self-assessment ('it is the teacher's responsibility, not mine'), as well as the impact of diverse educational backgrounds, can be managed by designing strong teaching strategies and the enhancement of the students' reflective learning. Good pedagogy could foster critical thinking through various forms of collaborative work. Self-assessment and collaboration are 
fundamental to the practice of the practising translator, and translation students should master both before they enter the profession.

\section{Assessment in education and evaluation \\ in the translation industry}

The client's assessment of a translation will not be quite the same as a translator trainer's assessment of a student translator's translation. Fraser (2010) discusses the tension between translation taught at university and translation in the 'real world' in '[t]he broader view: how freelance translators define translation competence' (2000:51-63). In regard to higher education, Kiraly (1995:6) differentiates between two types of translation: translation for professional goals and didactic translation for language learning, which, if recognized, might counter Fraser's suggested tension between the industry and academic training. So, how does higher education in the UK deal with this dichotomy between translation as an academic assessment process and translation as professional practice? Fraser's top-down empirical approach to translator training requires a professional translation brief, terminology support supplied by the translator trainer, good revision practice and feedback. Fraser notes that a good brief enables better free translation and fewer errors in the transfer. As professional feedback can be either rare or negative, it should be given a higher profile during training. The teacher's aim should be to teach students to revise more effectively and focus on their competence (Fraser 2010:59). In a longitudinal study of student translators and practising translators (Hansen 2013:49-64) it was demonstrated that whereas cognitive processes seem to be set early on and are part of the translator's personal make-up, translation styles establish themselves over a period of five to six years. Initially, students tend to focus on solving problems in the source language, rather than on style and text type adequacy (Fraser 2010:59). Teachers, therefore, need to make assessment criteria clear. Students need to be well equipped to manage work in a professional environment where assessment (criteria) may be less clear.

A broad historical overview of translator training in Europe (Anderman and Rogers 2000: 63-77) states that it remains an issue how to make translator training more responsive to changing market needs (an observation also made in Pym's (2003) report of an online forum). There should be a focus on project management and new genres of translation. But at the same time welltrained translators could set the standards for a new generation of translators.

\section{Professional organisations as gatekeepers of standards}

Translators can set spontaneous standards, organisations can maintain them. Western Europe and North America are renowned for communities of practice and professional structure often presented in linguist or translator organisations. The Institute of Translation and Interpreting in the UK supports its translators by offering many routes to CPD and sets standards by awarding different levels of memberships according to experience and qualifications. It offers its own examinations to practising translators in line with their level of membership. The Chartered Institute of Linguists supports linguists in general as well as translators, and its examination package has a much broader remit. In the field of translation and interpreting, CIOL offers exams designed for linguists working in the public services, e.g. courts, the health service and local government, such as the Diploma in Public Service Interpreting (DPSI). The Institute of Linguist's Educational Trust offers a wide range of language assessments, from the Certificate in Languages for Businesses, increasingly taken in UK secondary education, to 
the Diploma of Translation which is promoted as the 'gold standard for anyone wanting a career as a freelance translator or to work as a translator for international corporations worldwide and meets the need for a high-level professional translating qualification' (www.ciol.org.uk 2015). The Diploma consists of three units: written translation of a general text, written translation of a semi-specialised text in technology, business or literature. The third unit completes the second unit with texts in science, social science and law. The language combinations include circa 30 into English, circa 50 from English and 7 other European language combinations. Some UK universities include one or more units of the Diploma in Translations in their degree course. The quality of their exams is monitored independently and formally recognized by qualifications and exams regulator Ofqual. Training for DPSI and DipTrans is outsourced and provided online for many languages and monitored by CIOL.

In summary, both organisations ITI and CIOL are constantly aiming to raise standards among their membership. The number of candidates for their exams is small in comparison to the large number of qualified as well as unqualified providers of translation. The impact of organisations on translation quality is good but limited. Maybe the trump card to good quality translations is held on the work floor by translator and client combined. If the client demands a welldefined level of quality, the translator should offer that quality according to agreed and clearly defined standards. Clarity and transparency of quality and standards are instrumental in improving the status of translation and its providers.

\section{Conclusion}

Practising translators and LSPs may build walls to protect themselves from unqualified competitors, be it machine translation, fansubbers, crowdsourcers or rogue LSPs. Some shun teamwork, shut their eyes to a changing professional world in which translations will no longer be 'one-man-shows', but products of teamwork and assisted technology where existing standards have become ineffective. Do we need gatekeepers to guard the standards of professionalism in translation? There are several professional UK organisations which cater for the needs of linguists, translators and interpreters with the objective of setting and raising standards. but they cannot guarantee quality. The Chartered Institute of Linguists offers a wide range of specialist examinations in order to benchmark professional expertise. It finds itself supported by universities which include their translation and interpreting exams in their degree courses. ITI and CIOL offer opportunities for corporate professional development to their members in order to raise standards and they invite nonmembers to take their exams. Thus training and development are benchmarked and should lead to improved product quality, if the student translator has learnt how to involve the client in the setting of standards and translation quality.

In the field, an eclectic professional mix of translators, interpreters, academics and students meet and share experiences at academic or translator conferences, at webinars, online courses, through mailing lists or on forums. Particularly translator forums on the web, where credentials are less important, are likely to attract a wide spectrum of translation providers. ProZ. com actually supports crowdsourcing and thus enables professionals and amateurs to meet in, for instance, the Translators without Border Workspace. Freelance anime fansubbing is also posted on the forum. Amateur translators can be found elsewhere in the cloud such as Facebook, and in charity translations where commercial interests are not at stake. Fansubbers and subtitlers are classified as amateur translators that work for free. They operate successfully in a translation 
market with a different set of fit-for-purpose criteria. If all language providers, professional or amateur, recognize that their services can be delivered at different levels of quality to suit different audiences, there could be a place for all. And if they are clear in what they offer and about the quality of their product, it might encourage the client, who purchases the translation, to select and buy, rather than bid and then turn to a cheaper provider. A bargaining climate surrounding translations only leads to an undercutting practice which does not guarantee good quality, nor does it promote appropriate standards.

Clients will be able to assess translation quality if they provide translators with an instruction brief that is clear, comprehensive and workable. The translator would then be able to advise which model of standards or level of quality is appropriate. The brief should be set up in such a way that the translator can tick the satisfactory completion of each item and return it to the client with the translation. At the same time professional organisation need to enhance their visibility to members, but particularly to the industry that purchases language services. They should provide the means to support the standards which can be agreed between client and translator. Meanwhile, translator trainers can develop a new generation of translators who know how to assess and revise their own work, who can set quality standards and seek ways to develop them during their career.

\section{References}

Brown, G., Bull, J. \& Pendlebury, M. Assessing Student Learning in Higher Education. London and New York, Routledge, 1997.

Cronin, M. (2010). The Translation Crowd. http://ddd.uab.cat/pub/tradumatica/15787559n8a4.pdf. Accessed August 2015.

Fraser, J. The Broader View: How Freelance Translators Define Competence. Schäffner, C. \& Adab, B. (eds). Developing Translation Competence, Amsterdam and Philadelphia, John Benjamins, 2000, pp. 51-63.

Fry, H., Ketteridge, S. \& Marshall, S. (eds). A Handbook for Teaching and Learning in Higher Education: Enhancing Academic Practice. London, Kogan Page, 2005.

Gambier, Y. (2015). Beyond Borders: paradoxes and challenges. Journal of Siberian Federal University. Humanities \& Social Sciences, 8(2), 349-361.

Gouadec, D. Translation as a Profession. Amsterdam and Philadelphia, John Benjamins, 2007.

Hansen, G. Many Tracks lead to the goal. Way, C., Vandepitte S., Meylaerts, R. \& Bartłomiejczyk, M. (eds) Tracks and Treks in Translation Studies. Amsterdam and Philadelphia, John Benjamins, 2013, pp. 49-62.

House, J. Translation Quality Assessment: a Model Revisited. Tubingen, G. Narr, 1997.

Kiraly, D. C. Pathways to Translation: Pedagogy and Process. Kent, Ohio: Kent State University Press, 1995.

Lommel, A. (2013) Alternatives to certification. The International Journal for Translation and Interpreting Research. DOI: ti.105201.2013.r02. Accessed September 2015.

Martin, T. (2007). Managing risks and resources: a down-to earth view of revision. The Journal of Specialised Translation, 08:57-63. [Online] < http://www.jostrans.org/> Accessed March 2012.

Mitchell-Schuitevoerder, R. (2015). Rethinking “quality”. ITI Bulletin. March/April. 
Mitchell-Schuitevoerder, R. (2014). A Project-Based Syllabus Design - Innovative Pedagogy in Translation Studies. http://etheses.dur.ac.uk/10830/.

Moore, Miranda (ed.) (2015). The Linguist. March/April 2015.

Muzii, L. (2012). A Contrarian's View on Translation Standards, e-book, www.lulu.com.

Nord, C. Translating as a Purposeful Activity: Functionalist Approaches Explained. Manchester, St. Jerome, 1997.

O’Brien, Sh. (2012). Towards a Dynamic Quality Evaluation Model for Translation. The Journal of Specialised Translation, 17. [Online] <http://www.jostrans.org/issue17/art_obrien.pdf $>$ Accessed May 2014.

Pym, A. (2003). Redefining Translation Competence in an Electronic Age. In Defence of a Minimalist Approach. Meta: Translators' Journal, 48(4), 481-497.

Pym, A. Exploring Translation Theories. London, Routledge, 2010.

\title{
Повторное обращение
}

\section{к вопросам качества переводов и стандартов}

\section{Розмари Митчелл-Шутевордер \\ Университет Ньюкасла \\ Великобритания}

\begin{abstract}
Переводчики и поставщики лингвистических услуг неизменно предлагают свои услуги, провозглашая их превосходное качество. Они поддержсиваются профессиональными организациями устного и письменного перевода, которые подчеркивают свою приверженность $\kappa$ практикуюшим переводчикам, а также к иели повышения языковых навыков в интересах общества посредством аккредитованных квалификаций. Данная статья будет не только рассматривать понятие качества с точки зрения различных заинтересованных сторон в проиессе перевода от поставщиков до покупателей, но и рассматривать вопрос о том, могут ли новые модели стандартов и различных уровней качества внести большую ясность в переводческую отрасль. Для того чтобы улучшить качество переводов, важно обратить больше внимания на самооченку, а также на базовую подготовку переводчиков. Между тем профессиональные организации должны не только поддерживать и улучшать стандарты, но и способствовать большей видимости качества и стандартов для всех заинтересованных сторон, начиная с переводчика и заканчивая клиентом.
\end{abstract}

Ключевые слова: профессиональные организации, спецификации перевода, многоуровневые модели качества, стандарты, самооценка.

Научная специиальность: 10.00.00 - филологические науки. 